\title{
Mad Lit.: Introduction to a Special Issue of the Journal of Medical Humanities
}

\author{
Paul Crawford • Charley Baker • Brian Brown
}

Published online: 12 August 2011

(C) Springer Science+Business Media, LLC 2011

This special issue emerges as a result of papers delivered at the 1st International Health Humanities Conference: Madness \& Literature, funded by the Arts and Humanities Research Council, UK, and held at the Institute of Mental Health at the University of Nottingham, August 6-8, 2010. The conference, which included keynotes from Elaine Showalter (The Female Malady) and Kay Redfield Jamison (Touched By Fire), was hosted as part of a range of initiatives based at the University of Nottingham which we call 'Health Humanities' - an evolution of Medical Humanities towards greater inclusion of and engagement with allied health professionals including nurses, occupational therapists and those practicing the expressive therapies, as well as carers, service-users and a wider selfcaring public. Our aim is to address the growing and broadening demand from other professions to become involved and to include new sectors of the healthcare workforce, as well as informal carers who have often been left out of the medical humanities so far. Different disciplines have increasingly come to value the contribution made by the humanities, and fresh opportunities are emerging in healthcare for the development of new approaches in the humanities.

Our conference was a landmark attempt to bring some of these ideas together. Focussing on madness in all its guises, it was accompanied by a new website, www. madnessandliterature.org, which has so far attracted over 300 academic, clinical and lay members worldwide and offers numerous short reviews of 'Mad Literature' or 'Mad Lit.'-fiction and autobiography that documents and details a diverse range of human experience that falls within the category madness.

Why is 'Mad Lit.' generating such interest? As we note in our book, Madness in Post1945 British and American Fiction (Baker et al. 2010), it provides valuable and sometimes contrasting insights into the traumatising experience of mental illness, attitudes towards individuals deemed ill, and the treatments, social networks, institutions and historical or

P. Crawford $(\bowtie) \cdot$ C. Baker

School of Nursing, London Road Community Hospital, University of Nottingham, London Road, Derby DE1 2QY, UK

e-mail: paul.crawford@nottingham.ac.uk

B. Brown

Health \& Life Sciences, DeMontfort University, The Gateway, Leicester LE1 9BH, UK 
cultural contexts within which such experiences unfold. Indeed, Mad Lit. is a major part of what David Lodge, writing on the novel, calls 'the richest record we have of human consciousness' (Lodge 2002). Reading Mad Lit. offers a curious, personal and textually mediated experience where we enter the 'life-worlds' of characters and get a sense of what it might be like to be depressed, addicted to drugs or disrupted by psychosis. Toni Morrison captures something of the magic and fluency of this route to empathy in The Dancing Mind: 'The life of the book world is quite serious. Its real life is about creating and producing and distributing knowledge; about making it possible for the entitled as well as the dispossessed to experience one's own mind dancing with another's' (Morrison 1996).

In this special issue, we have selected nine papers that mark the richness of Mad Lit. and the chance for one's mind to dance with another's, extending beyond the more familiar range of British, American or European works to those of China and Malaysia and, more curiously perhaps, to incorporate graphic memoir.

Javier Saavedra Macias and Rafael Vélez Núñez provide a fascinating account of themes of the double in mythology, literature and in clinical work. Drawing upon 'postmodernist psychology,' the authors consider the dialogical relationship between psychopathology and literature. Sue Atkinson excavates the work and life of Bessie Head, providing a persuasive argument for her work to be conceived as forming both a survival strategy and as a working through of the lived reality of a complex and difficult life. Sarah Chaney provides a detailed and thorough analysis of the influence of fiction on late 19th-century definitions and explorations of self-mutilation, using Hawthorne's The Scarlet Letter as a case in point, before exploring the concomitant appearance of the definition of psychopathologies and social commentary in medical and fictional texts of the period. Birgit Linder's essay is a timely analysis of how 20th century Chinese writers such as Lu Xun, among others, deploy the theme of madness to generate social insight and to symbolize alienation during a period of profound cultural and social change. As such, her discussion marks a welcome and intriguing departure from Western writing and its focus, in particular, on creative genius. Similarly, Sheba D. Mani's essay on the grotesque female in Malaysian poems offers an insight into literature that is relatively unknown in the Anglophone world and indicates new ways of configuring the relationship between Bakhtinian theory, postcolonialism and poetry that captures the mental torment of the migrant. Isabelle Travis provides a useful and intriguing periodization of Robert Lowell's work in the light of developments in psychopharmacology which were ongoing at the time and Fred Ribkoff and Paul Tyndall write persuasively on Tennessee Williams' A Streetcar Named Desire, revisiting characterization in light of contemporary theories on trauma. Gary Winship explores the anti-chess metaphor in Samuel Beckett's novel, Murphy, in terms of the process of therapy adopted by Beckett's psychoanalyst, Wilfred Bion. Finally, using a unique blend of prose and image to form a graphic paper, Ian Williams explores the possibility that graphic novelists who produce 'graphic pathologies' may be searching for healing and catharsis through their productions.

We hope that readers find in this selection of essays a flavor of the many excellent presentations at the conference and the dramatic force of Mad Lit.- something that Paul Sayer, the author of Comforts of Madness, highlighted in a telling interview with Charley Baker: "From the time of Bedlam, people have been fascinated by psychiatric institutions and, often morbidly, by the processes and occasional cruelties human beings can inflict on each other. The state of 'madness' also infers a mysterious twilight zone of the mind, a condition in which the subject is out of control and anything can happen. Great stuff for a dramatic narrative, and a staple of prose fiction for centuries." Certainly, within the Mad Lit. element of the Health Humanities research programme and its International Health 
Humanities Network at Nottingham, we anticipate that research will continue to provide fertile material for academics, clinicians, service users, carers and the wider public.

\section{References}

Baker, C., Crawford, P., Carter, R., Lipsedge, M. \& Brown, B. Madness in Post-1945 British and American Fiction. Palgrave: London, 2010.

Lodge, D. Consciousness and the Novel. Secker \& Warburg: London, 2002.

Morrison, T. The Dancing Mind: Speech Upon Acceptance of the National Book Foundation Medal for Distinguished Contribution to American Letters. Alfred A. Knopf: New York, 1996. 